MARSHALLESE-ENGLISH DICTIONARY 
PALI LANGUAGE TEXTS: MICRONESIA

Social Science Research Institute

University of Hawaii

Donald M. Topping

Editor 


\title{
MARSHALLESE-ENGLISH DICTIONARY
}

\author{
TAKAJI ABO \\ BYRON W. BENDER \\ ALFRED CAPELLE \\ TONY DEBRUM
}

University of Hawaii Press

Honolulu 
The publication of this book is subsidized

by the government of the

Trust Territory of the Pacific Islands.

Copyright (C) 1976 by The University Press of Hawaii

All rights reserved

Printed in the United States of Americ:a

18

$\begin{array}{lll}21 & 20 & 19\end{array}$

\section{Library of Congress Cataloging in Publication Data}

Main entry under title:

Marshallese-English dictionary.

(Pali language texts : Micronesia)

Bibliography: $p$.

1. Marshall language-Dictionaries-English.

2. English language-Dictionaries-Marshall. 3. Names,

Geographical-Marshall Islands. 4. Marshall language-

Etymology-Names. I. Abo, Takaji, 1936- II. Series:

Pali language texts.

PL6255.Z5M3 499'.5 76-26156

ISBN-13: 978-0-8248-0457-2

ISBN-10: ()-8248-0457-0

This is one in a series of dictionaries compiled and edited with the aid of a specially developed system of computer programs, which also formatted the text for composition and produced the tapes to drive a digital character-generating phototypesetter.

University of Hawaii Press books are printed on acid-free paper and meet the guidelines for permanence and durability of the Council on Library Resources.

Printed by Sheridan Books, Inc.

www.uhpress.hawaii.edu 
For the

students and teachers

in the schools

of the

Marshall Islands 
